\title{
SOIL AND WATER MICROBIOTA AS BIOINDICATORS FOR THE ASSESSMENT ECOLOGICAL STATUS OF ECOSYSTEMS
}

\author{
Olga Hafiiak ${ }^{1}$, Lyudmyla Symochko, ${ }^{1,2^{*}}$ \\ ${ }^{1 *}$ Uzhhorod National University, Faculty of Biology, Voloshyna Str. 32, 88000, Uzhhorod, Ukraine; \\ ${ }^{2}$ Institute of Agroecology and Environmental Management NAAS, Metrologichna Str., 12, Kyiv, 03143, Ukraine; \\ *Corresponding Author Lyudmyla Symochko, e-mail:lyudmilassem@gmail.com; \\ lyudmila.symochko@uzhnu.edu.ua;
}

Received November 2021; Accepted December 2021; Published January 2022;

DOI: https://doi.org/10.31407/ijees12.136

\begin{abstract}
The article presents the results of monitoring the area adjacent to the Carpathian Biosphere Reserve for investigation of unauthorized landfills and examines the ecological status of these ecosystems. Four unauthorized landfills for solid waste in Pidgirna, Stanislav, Steryshory, and Feresok tracts with an area of 0.15 to 1.5 ha with a waste accumulation period of 12-22 years and different morphological composition were identified, which had a significant impact on the soil and water microbiota. Bioindication methods have shown changes in the microbial communities of soil and water under the direct influence of unauthorized landfills. Increased the number of organotrophic bacteria and micromycetes and decreased content of nitrogen-fixing microorganisms. The highest number of bacteria using mineral forms of nitrogen (25.36-28.61 million CFU/g. d. soil) and micromycetes (51.876.8 thousand CFU/g. d. soil) was in the soils of Pidgirna and Feresok with an advantage of 1.5-1.7 times and 2.53.8 times compared to the soil of the protected area. Results of the analysis of water microbiome showed that it is a sensitive indicator. The high number of anaerobic bacteria of the genus Clostridium was in the tract Feresok, so above the flow of the study area 3.69 thousand CFU / $\mathrm{ml}$ of water, in a place close to the landfill 6.22 thousand $\mathrm{CFU} / \mathrm{ml}$ of water, below the flow of 9.35 thousand $\mathrm{CFU} / \mathrm{ml}$ of water. Gram-positive bacteria of the genus Staphylococcus varied from the most polluted area in Feresok to the least polluted in Steryshory: 3.89 thousand $\mathrm{CFU} / \mathrm{ml}$ of water, downstream 7.35 thousand $\mathrm{CFU} / \mathrm{ml}$ of water. A close relationship was established between the duration of solid waste storage at a certain site and the level of soil phytotoxicity $(\mathrm{r}=0.92)$. In the soil of landfills in Pidgirna, Steryshory, and Feresok tracts, the phytotoxicity index is significant (over 50\%), which indicates a high level of soil ecosystem pollution and increased environmental risks in the area of unauthorized accumulation of solid waste.
\end{abstract}

Key words: soil, water, bioindication, ecosystem, microorganisms, landfills. 